\title{
Effects of Dexamethasone, Metoclopramide or Acepromazine on Emesis in Cats Sedated with Xylazine Hydrochloride
}

\author{
A. TOPAL, N. Y. GÜL \\ Department of Surgery, Faculty of Veterinary Medicine, Uludag University, Turkey
}

Received May 13, 2005

Accepted March 16, 2006

\begin{abstract}
Topal A., N. Y. Gül: Effects of Dexamethasone, Metoclopramide or Acepromazine on Emesis in Cats Sedated with Xylazine Hydrochloride. Acta Vet. Brno 2006, 75: 299-303.

This study was designed to determine antiemetic efficacy of prophylactic administration of dexamethasone, metoclopramide or acepromazine and their influence on sedation in cats sedated with xylazine hydrochloride.

Ten healthy adult cats ( 5 males and 5 females) were used. The prophylactic antiemetic effects of dexamethasone $(4 \mathrm{mg} / \mathrm{kg}$ of body weight, IM), metoclopramide $(0.4 \mathrm{mg} / \mathrm{kg}$ of body weight, IM), acepromazine $(0.1 \mathrm{mg} / \mathrm{kg}$ of body weight, IM) or saline $(0.9 \% \mathrm{NaCI})$ solution $(0.1 \mathrm{ml} / \mathrm{kg}$, IM) administered 1 hour before administration of xylazine hydrochloride $(2 \mathrm{mg} / \mathrm{kg}$, IM) was evaluated. Initially, the cats were given saline treatment (day 0); sequentially they were given dexamethasone, metoclopramide or acepromazine at 1 week intervals. After a xylazine injection, all cats were observed for 90 minutes for the assesment of frequency of emesis, and the time until the onset of the first emetic episode, and the determination of xylazine-induced sedation time.

Prior treatment with $4 \mathrm{mg} / \mathrm{kg}$ of dexamethasone significantly reduced the frequency of emetic episodes but no alteration was observed in the time until the onset of the first emetic episode after the xylazine injection. Metoclopramide and acepromazine did not alter the frequency of emetic episodes but metoclopramide significantly prolonged the onset of the first emetic episode.

Dexamethasone ( $4 \mathrm{mg} / \mathrm{kg}$, IM) significantly decreased the frequency of emetic episodes without affecting the time until the onset of the first emetic episode, xylazine-induced sedation in cats.
\end{abstract}

Antiemetic drugs, antiemetic effects, emetic episodes, sedation

Xylazine hydrochloride is widely used in biological and veterinary medical research as a sedative analgesic restraining agent. It is known that xylazine induces vomiting within a few minutes of systemic injection in cats and dogs (Ho et al. 2001; Hikasa et al. 1986; Hikasa et al. 1992a; Hikas a et al. 1992b; Colby et al. 1981). Xylazine has been shown to evoke vomiting through its actions on the emetic chemoreceptor trigger zone (CTZ) of the area postrema in cats (Colby et al. 1981; Hikasa et al.1992a; McCarthy and Boris on 1984) and dogs (Hikas a et al. 1986).

It has been shown that, both in cats (Colby et al. 1981; Hikas a et al. 1989; Hikas a et al.1992a) and dogs (Hik s a et al.1986; Hikas a et al.1992b), the emetic action of xylazine injected intramuscularly is mediated through $\alpha_{2}$-adrenoceptors, because this effect of xylazine is prevented only by $\alpha_{2}$-adrenoceptor antagonists, such as yohimbine, tolazoline, and phentolamine (Hikas a et al. 1989; Hikas a et al. 1992a).

On the other hand, recent studies have suggested that glucocorticoids, such as dexamethasone, may be involved in the control of vomiting induced by xylazine acting on the area postrema (Ho et al. 2001). Dexamethasone is a glucocorticoid that is effective in preventing chemotherapy-induced emesis in humans (Jones et al.1991; Spector et al. 1998; Wang et al.1999), cats (Rudd et al. 2000), dogs (Fukui and Yamamoto 1999), ferrets (Hawthorn and Cunningham 1990; Rudd and Naylor 1996), and pigeons (Tanihata et al. 2000).

Address for correspondence:

Assoc. prof. Dr. Ayse Topal

Department of Surgery

Faculty of Veterinary Medicine, Uludag University

16190 Bursa, Turkey
Phone: +902242347655

Fax : + 902242346395

E-mail: atopal@uludag.edu.tr

http://www.vfu.cz/acta-vet/actavet.htm 
Other studies have reported the antiemetic potential of phenothiazine in cats ( $\mathrm{McCarthy}$ and Borison 1984) and metoclopramide in dogs (Hika s a et al. 1986).

Xylazine has been widely used as a sedative in animals prior to performing many procedures, such as radiography, catheterization, and ultrasonography. However, emesis is frequently reported after xylazine administration in cats, which may distress the animal and also increase the risk of aspiration pneumonia.

Centrally acting drugs are more effective than peripherally acting drugs. Phenothiazine derivates (e.g. acepromazine) and metoclopramide inhibits the chemoreceptor trigger zone and increases gastric tone and peristalsis, both of which inhibit emesis (Hikasa et al. 1992a). On the other hand, only one study reported that pre-treatment with dexamethasone (4 or $8 \mathrm{mg} / \mathrm{kg}$, IM) decreased the number of emesis and prolonged latency of xylazine induced emesis in cats (Ho et al. 2001).

The present study was conducted on cats to determine which of these three drugs have an antiemetic effect on xylazine-induced emesis.

\section{Materials and Methods}

Animals

Healthy adult mixed-breed cats ( 5 males and 5 females) weighing from 2.3 to $4.5 \mathrm{~kg}$ (median, $3.8 \pm 0.5 \mathrm{~kg}$ ) were used for the study. Prior to the experiment they were sheltered individually in stainless-steel cages in an airconditioned room controlled at $22 \pm 2{ }^{\circ} \mathrm{C}$. All cats in each experiment were fed commercial dry food and water $\mathrm{ad}$ libitum and fasted for $12 \mathrm{~h}$ before the emetic experiment.

All experiments were conducted in accordance with the Animal Research Ethics Committee of the Uludag University of Turkey.

Experimental periods

Administration of drugs

The antiemetic effects of dexamethasone, metoclopramide or acepromazine and saline $(0.9 \% \mathrm{NaCI})$ solution given IM 1 hour before IM administration of xylazine were evaluated. Antiemetic drugs were injected in the semitendinous muscle of one leg. All cats were subjected to the same procedures, and each treatment was performed at a 1 week interval. On the first day, the cats were given saline solution $(0.1 \mathrm{ml} / \mathrm{kg}$ of body weight, IM), and on days 7,14 and 21 , they were given dexamethasone $(4 \mathrm{mg} / \mathrm{kg}, \mathrm{IM})$, metoclopramide $(0.4 \mathrm{mg} / \mathrm{kg}$, IM), and acepromazine $(0.1 \mathrm{mg} / \mathrm{kg}$, IM). Immediately after these injections, the cats were fed $100-150 \mathrm{~g}$ commercially produced dry food. One hour later, each cat was administered xylazine $(2 \mathrm{mg} / \mathrm{kg}, \mathrm{IM})$ in the semitendinous muscle of the other leg. The dosage was chosen on the basis of the effective dose to induce sedation on cats.

The cats were observed until the end of the sedative effect, according to Lerche et al. (2002). During this period, the time until the onset of the first emetic episode, the frequency of emesis, and the time until the onset of the sedative effect and sedation period were determined. The effects of these drugs on xylazine-induced sedation were evaluated.

\section{Drugs Used}

The drugs used and their sources were as follows; xylazine HCI (Rompun ${ }^{\circledR}, 2 \%$, Bayer Company, Leverkusen, Germany), dexamethasone sodium phosphate (Onadron ${ }^{\circledR}, 4 \mathrm{mg} / \mathrm{ml}$, I.E.Ulagay Company, Istanbul, Turkey), metoclopramide HCI ( Metpamid ${ }^{\circledR}, 1 \mathrm{mg} / \mathrm{ml}$, Sifar Company, Istanbul, Turkey), acepromazine (Vetranquil ${ }^{\circledR}, 1 \%$, Sanofi, Paris, France).

All doses were calculated on the basis of the drug base weight. All drugs were used as undiluted solution.

Emetic response

Emesis was scored as an "all or none" response; separate episodes of emesis were considered when the interval between bouts of vomiting exceeded 10 seconds. During the observation period after the injection of xylazine, the number of emetic episodes was counted. The time until the onset of the first emetic episode was recorded.

The beginning of a sedative response was recorded when the cat assumed sternal or lateral recumbency and was unable to stand. The time until the onset of sedation after administration of xylazine was recorded. Also the end of the sedative effect was recorded when the cat was able to stand and walk without aid.

Statistical Analysis

All data were reported as mean \pm SD. Data for the time until the onset of sedation and the sedation period, latency of emesis, frequency of emesis, after treatment with dexamethasone, metoclopramide or acepromazine were analyzed using the Wilcoxon signed-rank test. Values of $p \leq 0.05$ were considered significant. 


\section{Results}

The intramuscular injection of a standard dose of xylazine $(2 \mathrm{mg} / \mathrm{kg}$, IM) in saline group evoked vomiting incidence of $100 \%$ and mean latency of $2.8 \pm 1.0 \mathrm{~min}$. All cats vomited most of the food they were fed.

Dexamethasone completely prevented vomiting induced by xylazine in five of ten cats. On the other hand, pre-treatment with dexamethasone reduced incidence of xylazineinduced vomiting in the other five cats in this group, but did not delay significantly latency of vomiting (Table 1). In contrast, metoclopramide and acepromazine did not reduce incidence of xylazine-induced vomiting.

The time until the onset of the first emetic episode (mean $\pm \mathrm{SD}$ ) was $2.8 \pm 1.0$ minutes when the cats were administered saline. When the cats were administered dexamethasone, metoclopramide, and acepromazine prior to administration of xylazine, the time until the first emetic episodes $(p<0.05)$ were $6.5 \pm 1.7,6.7 \pm 1.0$ and $6.2 \pm 2.0 \mathrm{~min}$, respectively.

The number of episodes of emesis was $2.4 \pm 0.9$ for the saline treatment. Emetic episodes occured only in five cats of the dexamethasone group. The number of episodes of emesis was $1.4 \pm 0.5$ in five cats displaying emesis in the dexamethasone group $(p<0.05)$.

In all of the groups, xylazine caused CNS depression which was characterized by recumbency. The time until the onset of sedation was $6.8 \pm 2.3 \mathrm{~min}$ for saline treatment, and $8.2 \pm 1.4,9.3 \pm 5.7,7.3 \pm 3.6$ minutes for dexamethasone, metoclopramide and acepromazine, respectively.

The time until the onset of sedation was found longer in the metoclopramide group, compared to others $(p<0.05)$. Dexamethasone and acepromazine at the doses studied, and saline apparently did not alter the recumbency period induced by xylazine. However, pretreatment with metoclopramide delayed the latency period and also prolonged the sedation period $(p<0.05)$ after administration of xylazine.

\section{Discussion}

It was shown in the present study that a standard dose of xylazine $(2 \mathrm{mg} / \mathrm{kg}$, IM) induced vomiting in $100 \%$ of the cats, even when pre-treated with saline, metoclopramide $(0.4 \mathrm{mg} / \mathrm{kg}, \mathrm{IM})$, or acepromazine $(0.1 \mathrm{mg} / \mathrm{kg}$, IM). However, vomiting was induced only in $50 \%$ of the cats administered xylazine after pre- treatment with dexamethasone $(4 \mathrm{mg} / \mathrm{kg}$, IM). Moreover, dexamethasone significantly reduced the episodes of vomiting in the remaining cats. These cats displayed only $1.4 \pm 0.5$ episode of vomiting. These results were similar to the data obtained in a previous study on cats treated with xylazine (Ho et al. 2001).

In previous studies, antagonist of $\alpha_{1}$-adrenoceptors (prozasin or phenoxybenzamine), $\beta_{1}$-adrenoceptors (propranolol), dopaminergic receptors (domperidone), muscarinic receptors (atropine), 5-hydroxytryptamine 3 receptors, opioid receptors (naloxone) and histamine receptors (diphenhydramine) did not prevent xylazine induced vomiting (Hik a s a et al. 1989; Lucot 1989; Hikasa et al. 1992a). These results suggested that the emetic action of xylazine is mediated by central $\alpha_{2}$-adrenoceptors in cats. The $\alpha_{2}$-adrenoceptor antagonist, yohimbine, prevented vomiting induced by xylazine (Hikasa et al. 1989; Hikasa et al. 1992b). The antagonism of this specific $\alpha_{2}$-adrenoceptor is effective against xylazine-induced emesis, but it is also capable of antagonizing the sedative effect of xylazine (Ho et al. 2001).

It was first reported in 1981 that dexamethasone is an effective antiemetic in cancer patients receiving chemotherapy (Aapro and Alberts 1981). Since then, several studies have documented that dexamethasone is effective in preventing emesis caused by chemothrerapy in humans (Jones et al. 1991; Spector et al. 1998; Wang et al. 1999), cats (Rudd et al. 2000), dogs (Fukui and Yamamoto, 1999) ferrets (Haw thorn and Cunning ham, 1990; Rudd and Naylor 1996), and pigeons (Tanihata et al. 2000). 


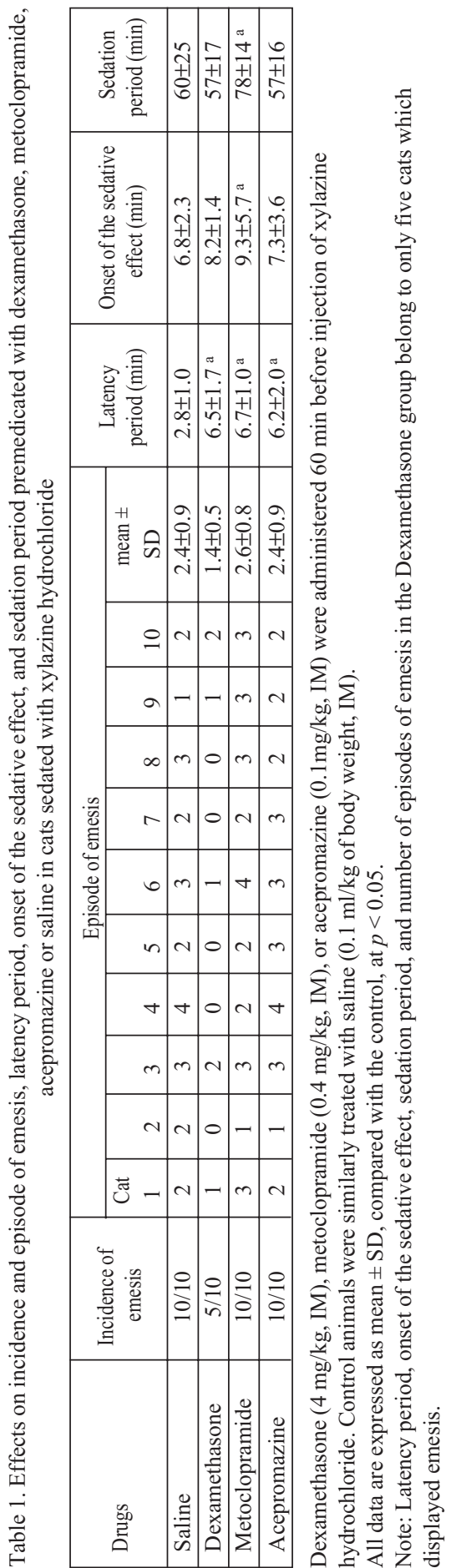

The exact mechanism by which dexamethasone exerts antiemetic action is not known, but it may involve central inhibition of prostaglandin synthesis and/or a decrease in serotonin turnover in the central nervous system (Wang et al. 1999). Additionally, corticosteroids are thought to stabilize membranes and affect the blood-brain barrier permeability to reduce the influx of emetogenic substances to the central nervous system (Hawthorn and Cunningham, 1990; Rudd and Naylor 1996). Xylazine reportedly induces vomiting via its action on the area postrema that is mediated by $\alpha_{2}$-adrenoceptor in cats (Colby et al. 1981; Hikasa et al. 1989; Hikasa et al. 1992a). Therefore the potential antiemetic mechanism of dexamethasone may involve the emetic pathway of the $\alpha_{2}$-adrenoceptor. There is evidence that glucocorticoid receptors and $\alpha_{2}$-adrenoceptors are abundant and coexist in the area postrema and nucleus of the solitary tract in the medulla oblongata (Morimoto et al. 1996). It is established that these nuclei in the medulla oblongata have substantial neuronal activity in regulation of the emetic reflex. The area postrema contains a chemoreceptive trigger zone that can be activated by endogenous or exogenous agents released into the circulation from the periphery (Lang 1999). Dexamethasone may therefore exert its antiemetic action through these nuclei. Further studies are required to elucidate the precise mechanisms of the antiemetic effect of dexamethasone.

In conclusion, the results of the present study indicate that xylazine-induced vomiting was reduced by pre-treatment with dexamethasone (4 mg/kg, IM) which however did not change the time until the onset of the first emetic episodes and did not disturb the sedative effect.

\section{Účinek dexametazonu, metoklopramidu nebo acepromazinu na zvracení koček při sedaci xylazin hydrochloridem}

Byl sledován antiemetický účinek dexametazonu, metoklopramidu nebo acepromazinu po profylaktické aplikaci kočkám před sedací xylazin hydrochloridem. Studie byla provedena na deseti zdravých, dospělých kočkách (5 samců/kocourů a 5 samic/koček). Jednu hodinu před aplikací xylazin hydrochloridu (2 mg. $\mathrm{kg}^{-1}$, i.m.) byl podán 
dexametazon (4 mg. $\mathrm{kg}^{-1}$ živé hmotnosti, i.m.), metoklopramid $\left(0,4 \mathrm{mg} \cdot \mathrm{kg}^{-1}\right.$, i.m. $)$, acepromazin $\left(0,1 \mathrm{mg} \cdot \mathrm{kg}^{-1}\right.$, i.m. $)$ nebo fyziologický roztok $\left(0,1 \mathrm{mg} \cdot \mathrm{kg}^{-1}, \mathrm{i} . \mathrm{m}\right.$.) a poté byl vyhodnocen jejich profylaktický antiemetický účinek. Nejprve byly kočky ošetřeny fyziologickým roztokem (den 0) a následně jim byl aplikován dexametazon, metoklopramid nebo acepromazin v týdenních intervalech. Po injekci xylazinu byly 90 minut pozorovány k zjištění počtu emetických epizod, doby do nástupu první epizody emeze, a k určení délky xylazinem indukované sedace. Předchozí aplikace $0,4 \mathrm{mg}$. $\mathrm{kg}^{-1}$ dexametazonu signifikantně snížila počet emetických epizod, ale nebyla zaznamenána žádná změna v čase nástupu první emetické epizody po aplikaci xylazinu. Metoklopramid a acepromazin neměly vliv na počet epizod emeze, ale metoklopramid signifikantně prodloužil čas do nástupu první epizody emeze. Dexametazon $\left(0,4 \mathrm{mg} \cdot \mathrm{kg}^{-1}\right.$, i.m.) signifikantně snížil počet epizod zvracení aniž by ovlivnil čas nástupu první epizody při xylazinem indukované sedace u koček.

\section{Acknowledgements}

This work was supported by the Uludag University of Veterinary Medicine. The authors also thank Mr. H. Tan for technical assistance.

\section{References}

AAPRO MS, ALBERTS DS 1981: Dexamethasone as an antiemetic in patients treated with cisplatin. New Engl J Med 305: 520

COLBY ED, McCARTHY LE, BORISON HL 1981: Emetic action of xylazine on the chemoreceptor trigger zone for vomiting in cats. J Vet Pharmacol Ther 4: 93-96

FUKUI H, YAMAMOTO M 1999: Methotrexate produces delayed emesis in dogs: A potential model of delayed emesis induced by chemotherapy. Eur J Pharmacol 372: 261-267

HAWTHORN J, CUNNINGHAM D 1990: Dexamethasone can potentiate the antiemetic action of a 5HT receptor antagonist on cyclophosphamide induced vomiting in the ferrets. Brit J Cancer 61: 56-60

HIKASA Y, TAKASE K, SAITO K, OGASAWARA S 1986: Antagonism of the emetic action of xylazine by alpha-adrenoceptor blocking agents. Eur J Pharmacol 130: 229-235

HIKASA Y, TAKASE K, OGASAWARA S 1989: Evidence for the involvement of alpha 2-adrenoceptors in the emetic action of xylazine in cats. Am J Vet Res 50:1348-1351

HIKASA Y, AKIBA T, IINO Y, MATSUKURA M, TAKASE K, OGASAWARA S 1992a: Central alphaadrenoceptor subtypes involved in the emetic pathway in cats. Eur J Pharmacol 229: 241-251

HIKASA Y, OGASAWARA S, TAKASE K 1992b: Alpha adrenoceptor subtypes involved in the emetic action in dogs. J Pharmacol Exp Ther 261: 746-754

HO CM, HO ST, WANG JJ, LEE TY, CHAI CY 2001: Effects of dexamethasone on emesis in cats sedated with xylazine hydrochloride. Am J Vet Res 62:1218-1221

JONES AL, HILL AS, SOUKOP M, HUTCHEON AW, CASSIDY J 1991: Comparison of dexamethasone and ondansetron in the prophylaxis of emesis induced by moderately emetogenic chemotherapy. Lancet, 338: $483-490$

LANG IM 1999: Noxious stimulation of emesis. Digestive Diseases and Sciences 44: 58-63

LERCHE P, MUIR WW, GRUBB TL 2002: Mask induction of anaesthesia with isoflurane or sevoflurane in premedicated cats. J Small Anim Pract 43: 12-15

LUCOT JB 1989: Blockade of 5-hydroxytryptamine3 receptors prevents cisplatin-induced but not motion- or xylazine-induced emesis in the cat. Pharmacol Biochem Be 32: 207-210

MCCARTHY LE, BORISON HL 1984: Cisplatin-induced vomiting eliminated by ablation of the area postrema in cats. Cancer Treat Rev 68: 401-404

MORIMOTO M, MORITA N, OZAWA H 1996: Distribution of glucocorticoid receptor immunoreactivity and mRNA in the rat brain. Neurosci Res 26: 235-269

RUDD JA, NAYLOR RJ 1996: An interaction of ondansetron and dexamethasone antagonizing cisplatin-induced acute and delayed emesis in the ferrets. Brit J Pharmacol 118: 209-214

RUDD JA, TSE JY, WAI MK 2000: Cisplatin-induced emesis in the cat: effect of granisetron and dexamethasone. Eur J Pharmacol 391:145-150

SPECTOR JI, LESTER EP, CHEVLEN EM 1998: A comparison of oral ondansetron and intravenous granisetron for the prevention of nausea and emesis accociated with cisplatin based chemotherapy. Oncologist 3: 432-438

TANIHATA S, IGARASHI H, SUZUKI M, UCHIYAMA T 2000: Cisplatin- induced early and delayed emesis in the pigeon. Brit J Pharmacol 130: 132-138

WANG JJ, HO ST, LEE SC, LIU YC, LIU YH, LIAO YC 1999: The prophylactic effect of dexamethasone on postoperative nausea and vomiting in women undergoing thyroidectomy. Anesth Analg 89 : 200-203 